\title{
Analysis of Biodiesel Cotton Seed Oil on Diesel Engine Performance
}

\author{
Semin $^{1}$, Adhi Iswantoro ${ }^{2}$, Gage Cendekiaji Hadi ${ }^{3}$
}

\begin{abstract}
- the world crisis of fossil fuel availability encourages the development to explore alternative energy which is possible to replace of fossil fuel. The use of biodiesel by using vegetable oil and animal fats is strived to the maximum extent possible, in order to maintain its sustainability. Cotton Seed oil (Ceiba Pentandra) is one alternative that can be used as a substitution fuel. There are four advantages of using Cotton Seed oil as a substitute fuel which are: produce a low level of pollutant, guaranteed availability, can be used for diesel engines with less or no modification and in certain mixes can increase engine lubrication that should increase engine life. The research was conducted through performance test of YANMAR TF85-MH diesel engine using Cotton Seed oil biodiesel with mixture of B30, B20 which has been compared with using diesel oil. From the results of experiment, it showed that the use of Cotton Seed oil has been increase performance than diesel fuel. The addition of biodiesel Cotton Seed oil percentage into the fuel provide greater power but it provides the higher fuel consumption.
\end{abstract}

Keywords—biodiesel Cotton Seed (ceiba pentandra), diesel engine, engine performance, renewable fuel.

\section{INTRODUCTION}

$\mathrm{T}$ oday, the use of diesel engines continues to increase in the transportation and industry sectors, the use of conventional diesel fuel is still the main choice for users in the operation of diesel engines. In the last few decades the world has been faced with a crisis of fossil fuel availability. The fact is, in big cities around the world absorb approximately three-quarters of the fossil fuels production [1]. In 2011 showed that the availability of petroleum in Indonesia is about 7.73 billion barrels [2], Petroleum reserves decreased by $10 \%$ annually [3]. But in the other hand, the consumption of fossil fuel increased by $6 \%$ annually [4]. Theoretically the fossil fuel source can be used not more than 30 years [5] with estimated oil reserves in Indonesia can only last up to 18 years [6]. Furthermore the current world crisis in middle east which one of the largest distributor of fossil fuel made the fossil fuel price increase [7]. It improve the development of alternative energy exploration which can be used to replace the fossil fuels that are depleting. Biodiesel is one consideration that is possible to overcome the problems that faced today. In Indonesia that has high potential production of biodiesel fuel [8]. Biodiesel itself can be produced by extract from vegetable oil or animal fats, that composed of three logchain fatty acids $[9,10,11]$. Some of the advantages of using biodiesel as fuel include: have a low level of pollutants [12,13], more can be guaranteed availability [14,15], can be used for existing diesel engines with little or no modifications [16], and on some certain blends can improves engine lubrication and increases engine life as

Semin, Department of Marine Engineering, Institut Teknologi Sepuluh Nopember, Surabaya 60111, Indonesia, E-mail: seminits@gmail.com

Adhi Iswantoro, Department of Marine Engineering, Institut Teknologi Sepuluh Nopember, Surabaya 60111, Indonesia, E-mail: adhi.iswantoro@gmail.com

Gage Cendekiaji Hadi, Department of Marine Engineering, Institut Teknologi Sepuluh Nopember, Surabaya 60111, Indonesia, E-mail: gage13@mhs.ne.its.ac.id it is virtually sulphur-free [17]. But unfortunately, it's more oxidative and causes corrosion by using diesel engine $[18,19,20]$.

Ong, et al, 2013 proves that biodiesel with jatropha curcas, Cotton (Ceiba pentandra) and Calophyllum ino have good performance to be used as fuel [21]. In line with Ong, Djamin 2010 also proves the addition of biodiesel up to $20 \%$ of fuel can improve engine performance, with the highest power and torque [17]. Santos [22] tested the performance of small diesel engines and large diesel engines by using biodiesel fuel oils from vegetable oil and animal fat. From these experiments showed the use of plant biodiesel and animal fat provide equally good performance against the performance of large diesel engines and small diesel engines [22].

In this article has been discussed about how the performance of diesel engines using biodiesel Cotton Seeds oil with mixed percentages B20 and B30. The variation were made to minimize of the high viscosity of Cotton Seed oil. The high viscosity of fuel can make the fuel injector to get fuel into the cylinder in an effective manner [23]. Performance of a diesel engine is one of the engine value test that needs to be taken into account because this performance affects the combustion process and emissions from a diesel engine.

Generally, performance analysis has at least 5 result variable, which are Power, Specific Fuel Consumption (SFOC), Break Mean Effective Pressure, Temperature Effectiveness and Torque [24-27]. But in this performance study, only two result variable were taken, which are Power and Specific Fuel Consumption. It is intended to simplify the analysis of emissions and combustion process data that has be done on the next step of study. This simplification is done by selecting the test parameters of combustion process and emission at maximum optimum rating power. Also this test parameter refers to the emission-taking rules that have been issued by Annex VI IMO that used of maximum power percentage as test parameter [28].

\section{METHOD}

In this article has been investigated the performance of YANMAR TF-M81H diesel engine by using Biodiesel from of Cotton Seed Oil (Ceiba Pentandra) with 20\% 
content percentage (B20), 30\% (B30) and Pertamina Dex as original fuel. This test can determine the engine performance by varying the load and engine speed during the experiment.

Engine setup is done by preparing YANMAR TF85$\mathrm{MH}$ diesel engine and connected it with alternator. The alternator has convert the mechanical power from the crankshaft rotation into electrical power and distribute it to a power panel. The power panel has act as a light loader whose load rating has be one of the parameters of the test. The engine rotation is controlled by using tachometer. Ampere meters and volt meters are embedded on the electrical grooves between the alternator and the power panel to measure the voltage and current that generated by the alternator.

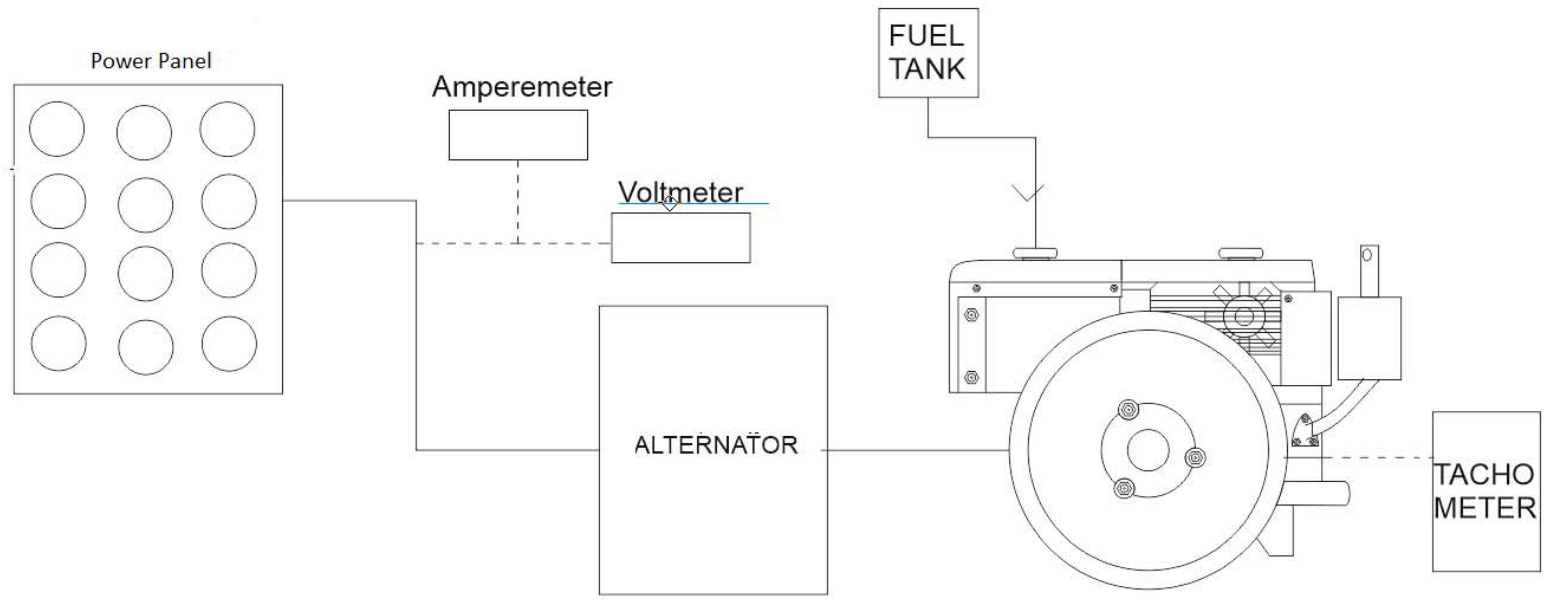

Figure. 1. Engine Setup of Biodiesel Cotton Seed Performance Test

The varying rotation used in this experiment varies from 1800 RPM to 2200 RPM, the RPM variation serves to estimate the maximum power value in certain RPM. For the loading used varied from 1000 watts to 5000 watts. The variable data to be taken and in the analysis is power and fuel consumption (SFOC).

Power value can be obtained by following this equation:

$P=\frac{V \times I \times \cos \theta}{\eta g e n \times \eta \operatorname{slip}}$

Where,

$\begin{array}{lll}\mathrm{P} & = & \text { Power (kWh) } \\ \mathrm{V} & = & \text { Voltage (Volt) } \\ \mathrm{I} & = & \text { Current (Ampere) } \\ \text { Dgen } & = & \text { Generator Efficiency } \\ \text { DSlip } & = & \text { Slip Efficiency }\end{array}$

The fuel consumption value can be obtained by following thus equation:

$S F O C=\frac{\rho \times V}{t \times P}$

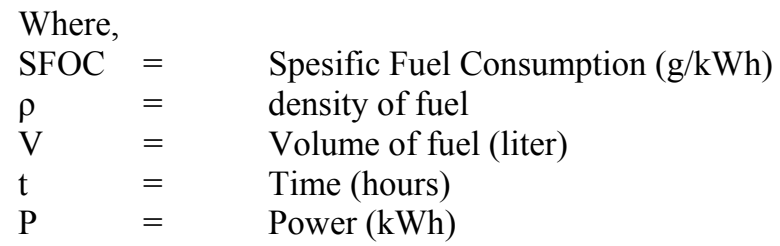

The amount of fuel consumption is directly proportional to the amount of emissions value. Usually, if the fuel consumed has been increased, the amount of exhaust emissions also increased [29]. These variables can be used as reference in combustion process and emission testing in the next step.

\section{RESULTS AND DISCUSSION}

A. Performance and SFOC Biodiesel Cotton Seed B20

The highest $20 \%$ biodiesel (B20) mixture is generated when the engine is loaded with 5000 watts and 2203 RPM engine turnover with $5.005 \mathrm{KW}$ and fuel consumption of $341.555 \mathrm{~g} / \mathrm{kWh}$. In the same table it appears the lowest fuel consumption at 4000 watt load with 1901 RPM engine, SFOC produced $292.118 \mathrm{gr} /$ $\mathrm{kWh}$ with power produced $3,366 \mathrm{~kW}$. Table 1 . shows the power and SFOC result of biodiesel Cotton Seed use. In Table 1 there are a cut off that were made to simplify combustion and emission data that based on optimal condition.

\section{B. Performance and SFOC Biodiesel Cotton Seed B30}

In the $30 \%$ biodiesel mixture (B30) the highest power is generated when the engine is given 5000 watt load and 2203 RPM engine turnover with the generated power of $5.191 \mathrm{KW}$ and the fuel consumption is $376.158 \mathrm{gr} /$ $\mathrm{kWh}$. In the same table it appears the lowest fuel consumption at 4000 watt load with 1905 RPM engine spin, SFOC produced $317.162 \mathrm{gr} / \mathrm{kWh}$ with the power generated 3,431 kW. The Performance and SFOC result of biodiesel B30 use showed in Table 2.

From the two compositions of biodiesel mixtures $(30 \%$ and $20 \%$ ) the highest power appears at 5000 watt load and 2203 RPM engine turnover. Similarly, fuel consumption, the lowest point is on the load of 4000 Watts and the engine rotation of about 1900 RPM. In Table 2 there are a cut off that were made to simplify 
combustion and emission data that based on optimal condition.

\section{Performance and SFOC Pertamina Dex Fuel BO}

By comparing the results of the performance of diesel engines by using kerosene seed oil and conventional fuel (diesel), it appears that diesel engines with Cotton Seed oil have better performance compared to diesel engines using diesel fuel. The findings are not much different from the findings of Setyawardhani [30], the performance of machines with rubber seed biodiesel has a greater power than the diesel fuel, although the highest performance at engine speeds under 2000 RPM, while using the highest performance biodiesel of Cotton Seeds with load above 2000 RPM [30]. The result of power and SFOC that provided by using B0 fuel is showed on Table 3 . Table 3 there are a cut off that were made to simplify combustion and emission data that based on optimal condition.

TABLE 1.

RESULTING POWER AND SFOC THAT BASED ON ENGINE SPEED USING B30 MIXTURE

\begin{tabular}{cccc}
\hline Load (watt) & RPM Engine & Power $(\mathbf{k W h})$ & SFOC $\mathbf{( g r} / \mathbf{k W h})$ \\
\hline 1000 & 1806 & 0.69 & 877.67 \\
2000 & 1809 & 1.53 & 551.55 \\
3000 & 1801 & 2.36 & 428.89 \\
$\mathbf{4 0 0 0}$ & $\mathbf{1 8 0 9}$ & 3.12 & 397.31 \\
5000 & 1807 & 3.70 & 400.22 \\
1000 & 1905 & 0.75 & 879.97 \\
2000 & 1906 & 1.69 & 421.08 \\
3000 & 1903 & 2.62 & 321.56 \\
$\mathbf{4 0 0 0}$ & $\mathbf{1 9 0 5}$ & 3.43 & 317.16 \\
5000 & 1902 & 4.07 & 491.36 \\
1000 & 2005 & 0.85 & 714.48 \\
2000 & 2002 & 1.88 & 502.04 \\
3000 & 2009 & 2.89 & 346.09 \\
$\mathbf{4 0 0 0}$ & $\mathbf{2 0 0 3}$ & 3.77 & 333.79 \\
5000 & 2001 & 4.48 & 352.65 \\
1000 & 2108 & 0.94 & 618.26 \\
2000 & 2101 & 2.07 & 474.30 \\
3000 & 2100 & 3.15 & 381.69 \\
4000 & 2109 & 4.16 & 412.25 \\
5000 & 2101 & 4.85 & 408.63 \\
1000 & 2205 & 1.05 & 540.17 \\
2000 & 2205 & 2.25 & 418.53 \\
3000 & 2208 & 3.44 & 407.56 \\
4000 & 2201 & 4.52 & 402.11 \\
5000 & $\mathbf{2 2 0 3}$ & 5.19 & 376.16 \\
\hline
\end{tabular}


TABLE 2 .

RESULTING POWER AND SFOC THAT BASED ON ENGINE SPEED USING B20 MIXTURE

\begin{tabular}{|c|c|c|c|}
\hline Load (watt) & RPM Engine & Power (kWh) & SFOC (gr/kWh) \\
\hline 1000 & 1803 & 0.67 & 882.93 \\
\hline 2000 & 1800 & 1.49 & 543.79 \\
\hline 3000 & 1802 & 2.33 & 416.12 \\
\hline 4000 & 1804 & 3.07 & 389.28 \\
\hline 5000 & 1804 & 3.69 & 402.20 \\
\hline 1000 & 1901 & 0.74 & 870.64 \\
\hline 2000 & 1905 & 1.67 & 436.21 \\
\hline 3000 & 1901 & 2.57 & 301.17 \\
\hline 4000 & 1901 & 3.37 & 292.12 \\
\hline 5000 & 1902 & 4.02 & 405.03 \\
\hline 1000 & 2001 & 0.82 & 716.22 \\
\hline 2000 & 2003 & 1.85 & 480.24 \\
\hline 3000 & 2005 & 2.84 & 319.52 \\
\hline 4000 & 2003 & 3.73 & 309.46 \\
\hline 5000 & 2001 & 4.41 & 310.66 \\
\hline 1000 & 2104 & 0.93 & 583.98 \\
\hline 2000 & 2104 & 2.01 & 439.75 \\
\hline 3000 & 2101 & 3.11 & 360.67 \\
\hline 4000 & 2105 & 4.09 & 366.91 \\
\hline 5000 & 2105 & 4.83 & 359.50 \\
\hline 1000 & 2202 & 1.05 & 522.48 \\
\hline 2000 & 2202 & 2.21 & 401.56 \\
\hline 3000 & 2203 & 3.40 & 350.27 \\
\hline 4000 & 2203 & 4.44 & 355.86 \\
\hline 5000 & 2203 & 5.01 & 341.55 \\
\hline
\end{tabular}

TABLE 3 .

RESULTING POWER AND SFOC THAT BASED ON ENGINE SPEED USING B0 FUEL

\begin{tabular}{|c|c|c|c|}
\hline Load (watt) & RPM Engine & Power (kWh) & SFOC (gr/kWh) \\
\hline 1000 & 1801 & 0.47 & 845.37 \\
\hline 2000 & 1801 & 1.11 & 442.74 \\
\hline 3000 & 1798 & 1.74 & 389.38 \\
\hline 4000 & 1800 & 2.37 & 323.86 \\
\hline 5000 & 1800 & 2.88 & 334.11 \\
\hline 1000 & 1902 & 0.56 & 705.85 \\
\hline 2000 & 1901 & 1.22 & 472.43 \\
\hline 3000 & 1902 & 1.98 & 359.62 \\
\hline 4000 & 1898 & 2.58 & 361.34 \\
\hline 5000 & 1900 & 2.72 & 335.74 \\
\hline 1000 & 2001 & 0.66 & 767.51 \\
\hline 2000 & 2001 & 1.38 & 441.92 \\
\hline 3000 & 2002 & 2.18 & 351.91 \\
\hline 4000 & 2000 & 2.84 & 349.09 \\
\hline 5000 & 2002 & 3.62 & 359.02 \\
\hline 1000 & 2099 & 0.78 & 705.03 \\
\hline 2000 & 2099 & 1.60 & 455.54 \\
\hline 3000 & 2101 & 2.47 & 355.69 \\
\hline 4000 & 2102 & 3.29 & 349.78 \\
\hline 5000 & 2101 & 3.32 & 335.86 \\
\hline 1000 & 2200 & 0.90 & 754.76 \\
\hline 2000 & 2202 & 1.81 & 503.30 \\
\hline 3000 & 2200 & 2.70 & 357.55 \\
\hline 4000 & 2202 & 3.58 & 309.15 \\
\hline 5000 & 2200 & 4.35 & 249.71 \\
\hline
\end{tabular}




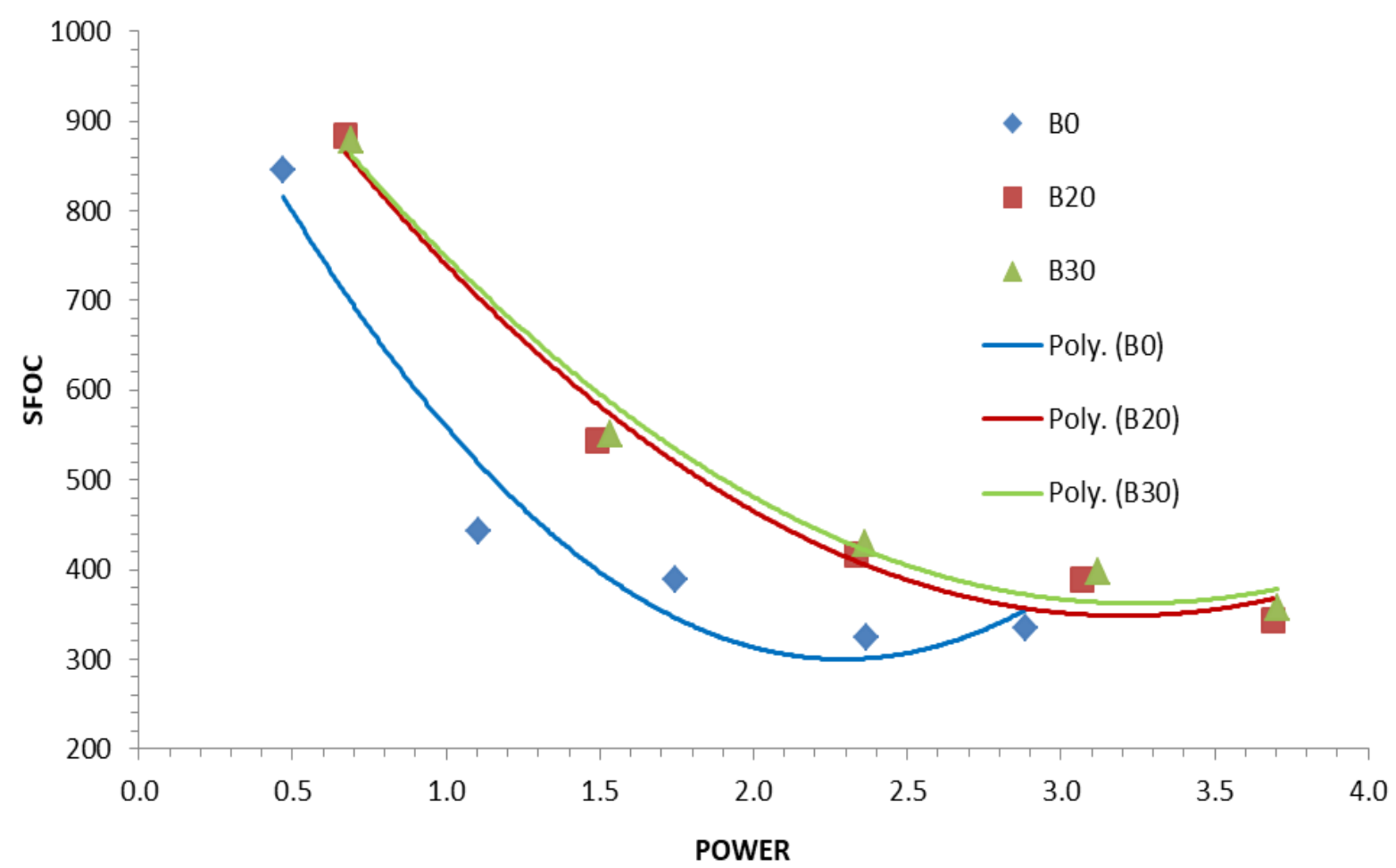

Figure. 2. Comparison between Power and SFOC on Fuel Type Biodiesel Cotton Seed B20, B30 and Pertamina Dex B0 at 1800 RPM

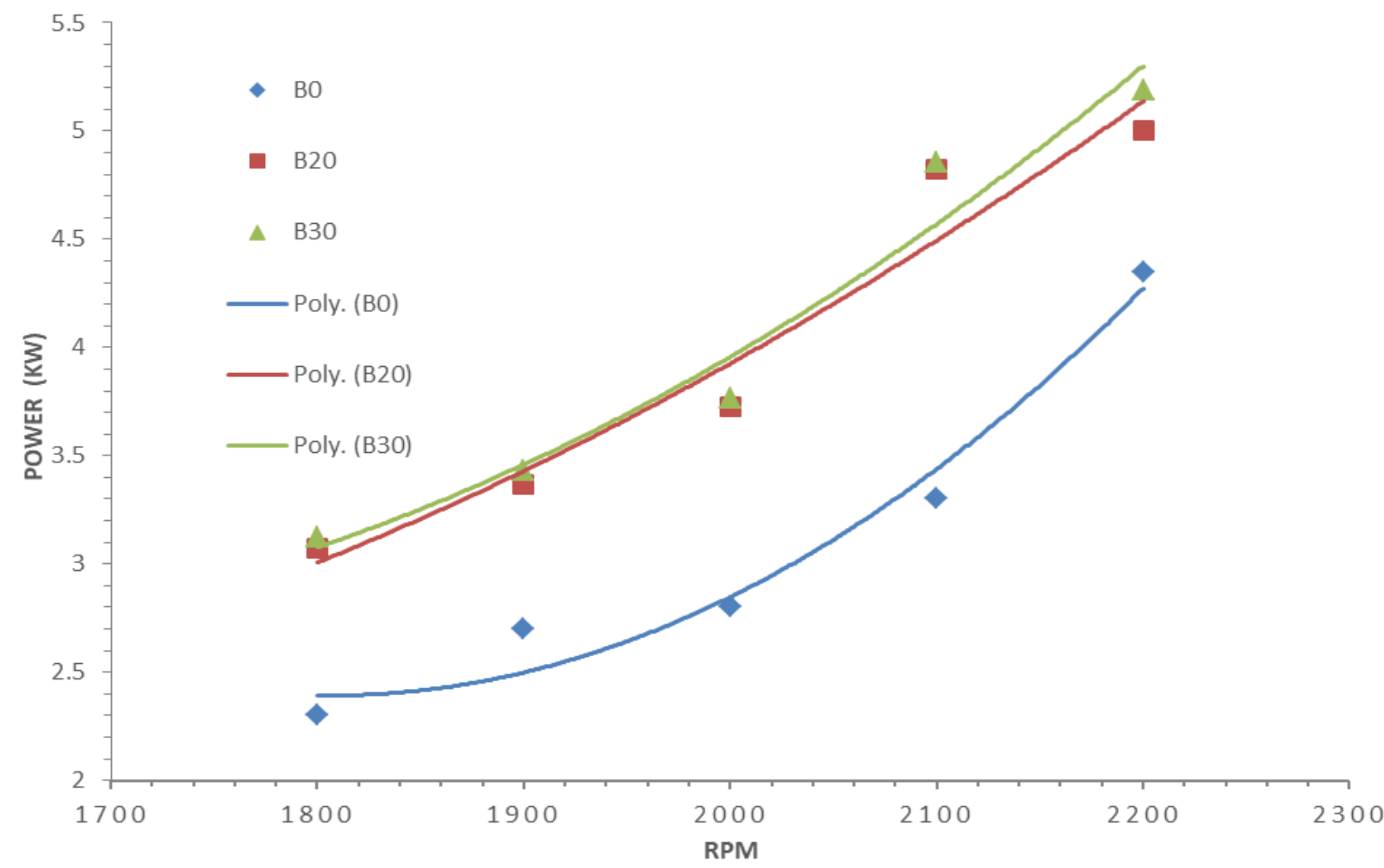

Figure. 3. Comparison of Optimal Power with Engine RPM Using Fuel Type Biodiesel Cotton Seed B20, B30 and Pertamina Dex B0

D. Comparison of Power and SFOC of Biodiesel Cotton Seed B20, B30 and Pertamina Dex B0 at $1800 R P M$

Based on Figure 2, it can be seen that with the increasing percentage of biodiesel content in fuel has been increase of SFOC, it proved by the significant difference in the comparison of SFOC B0 and B20-B30 values. The highest value of SFOC is fueled by B30 which is worth $877 \mathrm{~g} / \mathrm{kWh}$. However, from the graph it can be seen that the power generated from the use of Biodiesel Seeds B20 and B30 gained a higher power value compared to $\mathrm{B} 0$. This indicates that the addition of the percentage of seeds of Cotton Seed biodiesel in burning causes increase in the value of power produced. The most power generated by biodiesel fuel B30 with a power of $3.122 \mathrm{~kW}$. Followed by B20 which generates power of $3.071 \mathrm{~kW}$ and B0 which generates power of $2.44 \mathrm{~kW}$. So from the graph it can be concluded that the 
higher percentage of Cotton Seed biodiesel in fuel then produce higher value of power, but besides that addition of the percentage also cause increase of fuel consumption. The increasing SFOC may be contributed by higher density.

\section{E. Comparison of Optimal Power and Maximum} Power with RPM Using Biodiesel Cotton Seed B20, B30 and Pertamina Dex BO

On Figure 3, shows the comparison between the optimal power value with the Engine RPM while using Biodiesel Cotton Seed Mixture B20, B30 and B0. The point selection on the graph is done by selecting the power with the smallest SFOC value on each load. The power point with the smallest SFOC value is assumed to be the point where the loading produces optimal power. All test fuels obtain the highest optimum power at 2200 rounds with a constant increase in power value in each increment. B30 biodiesel fuel is ranked the highest maximum power with a total power of $5,191 \mathrm{~kW}$. Meanwhile Biodiesel B20 is ranked second with a power value of $5,005 \mathrm{~kW}$ followed by Pertamina Dex with a
Power Comparison with SFOC against Fuel Type Biodiesel Cotton Seed B20, B30 and Biodiesel WCO $\mathrm{B} 20, \mathrm{~B} 30$ at $1800 \mathrm{RPM}$.

F. Power Comparison with SFOC against Biodiesel Cotton Seed B20, B30 and Biodiesel WCO B20, B30 at $1800 \mathrm{RPM}$

On figure 4 shows the power ratio and SFOC generated from the biodiesel fuel of Cotton Seeds and the result of the use of used oil biodiesel in the YANMAR TF-M81H engine which has been investigated by Susi N, et al [25]. From the graph it can be concluded that the mean value of SFOC produced by Cotton Seed biodiesel is ranked higher than the value generated by biodiesel of Waste Vegetable oil on the percentage of mixture of B20 and B30. However, the highest SFOC value is occupied by B20 Waste Oil with SFOC value of $972 \mathrm{~g} / \mathrm{kWh}$ and the lowest SFOC is occupied by B30 Waste Vegetable Oil with SFOC value of $331 \mathrm{~g} / \mathrm{kWh}$. Besides, it can be seen that biodiesel of Cotton Seeds B20 and B30 increase power when compared with biodiesel of B20 and B30 Waste Vegetable oil.

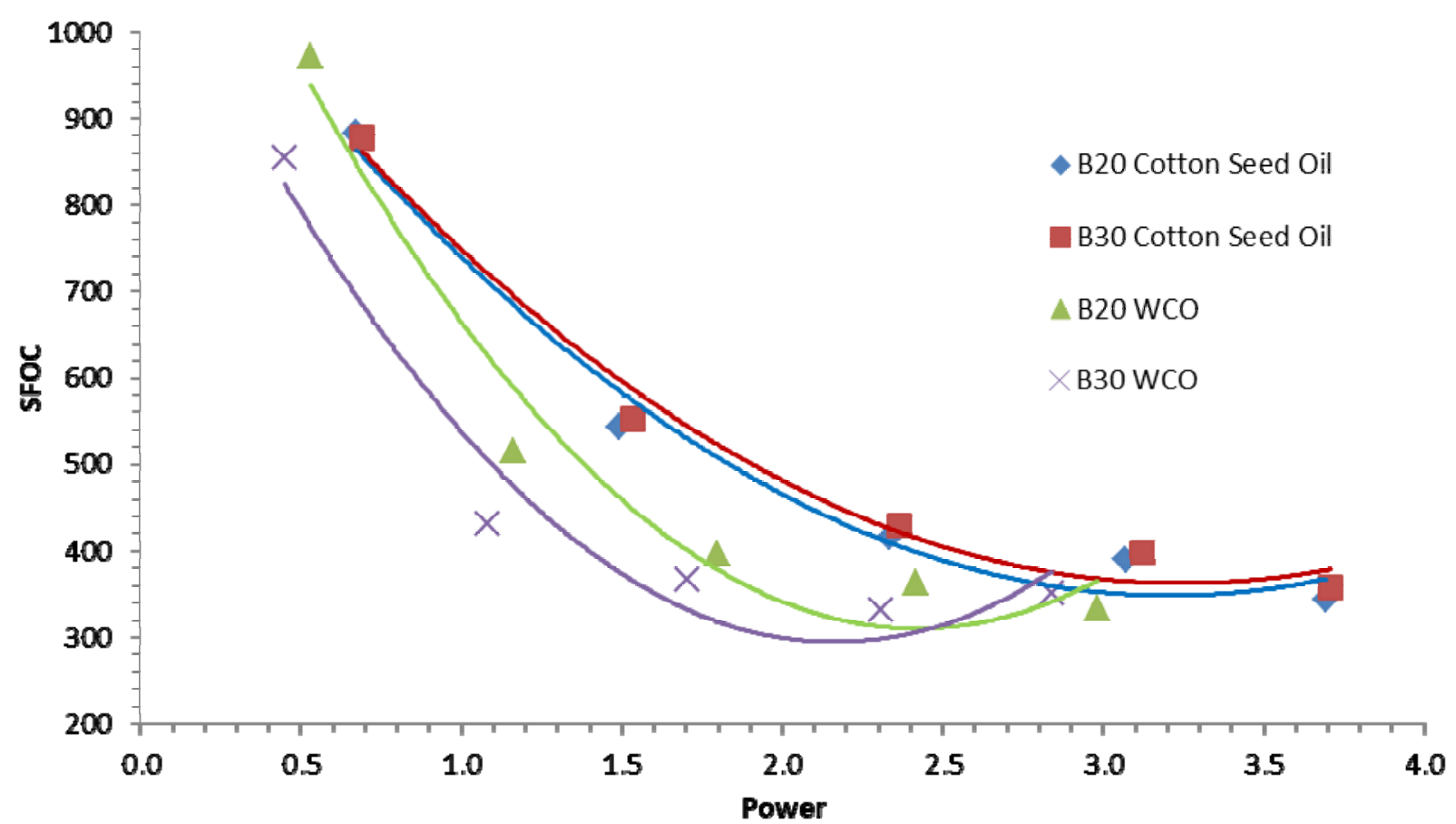

Figure. 4. Power Comparison with SFOC Against Fuel Type Biodiesel Cotton Seed B20, B30 and Biodiesel WCO B20, B30 at Round 1800 RPM

\section{CONCLUSION}

Based on the performance test results of YANMAR TF-M81H diesel engine, the addition of Biodiesel Cotton Seed percentage to the fuel has an effect on the performance of diesel engine.

- The percentage of biodiesel Cotton Seed in fuel affects the value of SFOC. The higher the percentage number of Cotton Seed biodiesel the higher the SFOC.

- The percentage of Cotton Seed biodiesel in fuel affects of power value. The greater percentage value of biodiesel Cotton Seed then the power generated has also be greater.
- The percentage of Cotton Seed biodiesel in fuel affects optimum power and maximum power value. The higher the percentage of Cotton Seed biodiesel, the optimum power and maximum power generated also increase.

Based on the results of comparative analysis of performance test of the use of Cotton Seed biodiesel and the use of waste vegetable oil biodiesel on diesel engine YANMAR TF-M81H has a significant difference.

- The results of the use of biodiesel of B20 and B30 Cotton Seeds produce higher power compared with the performance results of B20 and $\mathrm{B} 30$ biodiesel WCO. 
- The use of Cotton Seed biodiesel B20 and B30 results in higher SFOC values compared to SFOC values generated by the use of cooking oil.

Based on the results of the YANMAR TF-M81H diesel engine performance test, Biodiesel Cotton Seed oil with $30 \%$ percentage (B30) produces the highest average power, optimum power and maximum power when compared to other test fuel and power consumption of oil biodiesel WCO. But, Biodiesel Cotton Seed Oil B30 produces the highest fuel consumption. In the other hand, Biodiesel WCO B30 produces the lowest fuel consumption.

\section{REFERENCES}

[1] Peter, D "Renewable Energy and the City: Urban life in age of fossil fuel depletion and climate change," Institute for Global Environmental Strategies, Kitakyushu, Japan, 2002.

[2] Andre D, Semin, Tjoek S "Analisa Penggunaan Bahan Bakar Bioethanmol dari Batang Padi Sebagai Campuran Pada Bensin," Journal of Teknik POMITS, 2014, Vol. 3, No.1, ISSN: 2337-3539

[3] Bambang "Biodiesel sumber energi alternative pengganti solar yang terbuat dari ekstraksi minyak jarak pagar," Trubus Agrisarana Surabaya, 2006.

[4] Suroso "Kilang pengolahan BBM dioptimalkan,"Harian Pagi Jawa Pos, March 11' 2005.

[5] Semin, "Analysis of Biogas as An Alternative Fuel for Electric Generator Engine in Bawean Island-Indonesia," International Journal of Applied Engineering Research 2015, Volume 10, Number 15 pp 35313-35317 ISSN 0973-4562

[6] Nanang J, Made A, Semin "Penentuan Properties Bahan Bakar Batubara Cair Untuk Bahan Bakar Marine Diesel Engine,” Journal of Teknik POMITS Vol. 1,No. 1 (2012) ISSN: 2301-9271

[7] Semin, Awang I, Rosli A, "An Overview of Compressed Natural Gas as an Alternative Fuel and Malaysian Secenario," European Journal of Scientific Research 2009, Vol 34 No.1 pp 6-15 ISSN 1450-216X

[8] Priyohadi K, Aguk Z, Semin "Analisa Prediksi Potensi Bahan Baku Biodiesel Sebagai Suplemen Bahan Bakar Motor Diesel di Indonesia," Journal of Teknik POMITS Vol. 2,No. 1 (2013) ISSN: 2337-3539

[9] Singh SP, Singh D. Biodiesel production through the use of different sources and characterization of oils and their esters as the substitute of diesel: a review. Renewable and Sustainable Energy Reviews 2010;14:200-16.

[10] Jain S, Sharma MP. Prospects of biodiesel from Jatropha in India: a review. Renewable and Sustainable Energy Reviews 2010;14:763-71.

[11] Mata TM, Martins AA, Caetano NS. Microalgae for biodiesel production and other applications: a review. Renewable and Sustainable Energy Reviews 2010;14:217-32.

[12]Lin CY, Lin HA. Diesel engine performance and emission characteristics of biodiesel characteristics of biodiesel produced by the peroxidation process. Fuel 2006;85:298-305.

[13] Mamat R, Abdullah NR, Hongming Xu, Wyszynski ML, Tsolakis A. Effect of fuel temperature on performance and emissions of a common rail diesel engine operating with rapeseed methyl ester (RME). SAE Technical Paper No. 2009- 01-1896

[14] Dorado MP, Ballesteros E, Arnal JM, Gomez J, Lopez FJ. Exhaust emissions from a diesel engine fueled with transesterified waste olive oil. Fuel 2003;82:1311-5.

[15]Khan SA, Hussain RMZ, Prasad S, Banerjee UC. Prospects of biodiesel production from microalgae in India. Renewable and Sustainable Energy Reviews 2009;13:2361-72.

[16]Meher LC, Sagar DV, Naik SN. Technical aspects of biodiesel production by transesterification - a review. Renewable and Sustainable Energy Reviews 2006;10(3):248-68.

[17]Djamin, et all "Pengaruh Komposisi Biodiesel Terhadap Kinerja Mesin dan Emisi Gas Buang," J. Tek. Ling., vol. 11No 3, pp 381387. ISSN 1441-318X, 2010.

[18]Sgroi M, Bollito G, Saracco G, Specchia S. BIOFEAT: biodiesel fuel processor for a vehicle fuel cell auxiliary power unit; study of the feed system. Journal of Power Sources 2005;149:8-14.

[19]Tsuchiya T, Shiotani H, Goto S, Sugiyama G, Maeda A. Japanese standards for diesel fuel containing 5\% FAME blended diesel fuels and its impact on corrosion. SAE Technical Paper No. 2006-013303.

[20] Jain S, Sharma MP. Stability of biodiesel and its blends: a review. Renewable and Sustainable Energy Reviews 2010;14:667-78.

[21] Ong, et all, "Engine Performance and emissions using Jatropha Curcas, Ceiba Pentandra and Calophyllum inophyllum biodiesel in a CI diesel engine," [Online] Available from: Journal Homepage: www.elsivier.com/locate/energi [Accessed 2016 December 30]

[22] Santos, et all "A Comparative Study on The Engine Performance and Exhaust Emissions of Biodiesel form Various Vegetable Oils and Animal Fat," Journal of Sustainable Bioenergy Systems, 2015 5, 89-103 Published Online September 2015 in SciRes. http://www.scirp.org/journal/jsbs

[23]Rosli A, Semin, Abdul R "Effect of Engine Performance for Four Stroke Diesel Engine Using Simulation" Journal of KONES Powertrain and Transport Published Online 2008 in Reschgate https://www.researchgate.net/

[24] Muhammad,R "Expriment and simulation study of single cylinder diesel engine performance, using soybean oil biodiesel," Bachelor Thesis Institut Teknologi Sepuluh Nopember Surabaya, 2016

[25] Susi,N “Analisis Pengaruh Angka Iodin Terhadap Performa Motor Diesel dengan Bahan Bakar Biodiesel B20 dan B30 dari Waste Cooking Oil," Jurnal Teknok ITS Vol 4 No. 1, ISSN: 2337-3539

[26] Gaurav, et all, "Diesel Engine Performance and Emission Analysis using Biodiesel from Various Oil Sources-Review," J. Mater. Environ Sci Vol 4 No.4 pp 434-447 ISSN: 2028-2508

[27]Rosli A, Semin, Awang I "The performance and emissions characteristics of a compressed natural gas spark ignition engine," Journal of KONES Powertrain and Transport Vol. 15, No 22008

[28\}IMO "Emission Test Regulation," Annex Marine Polution Regulation VI, 2016

[29]Ayudhia P, Gusti, Semin, "The Effect of Vessel Speed on Fuel Consumption and Exhaust Gas Emission," American Journal of Engineering and Applied Sciences 2016, 9(4): 1046,1053

[30] Setyawardhani, et all "Uji Kinerja Biodiesel dari Minyak Biji Karet," Ekuilibrium Vol 11 No 2. pp 85-88 ISSN: 1412-912

[31]Semin, Adhi Iswantoro, Fatekhun Faris, "Performance and NOx Investigation on Diesel Engine using Cold EGR Spiral Tube: A Review", International Journal of Marine Engineering Innovation and Research, 2017, Vol. 1, No. 3, ISSN: 2548-1479

[32]Beny C, Aguk Zuhdi Muhammad Fathallah, Semin,Nauva Pahlevi, "Effect of Water Fuel Emulsion on Performance and NOx Emissions of Diesel Engine", International Journal of Marine Engineering Innovation and Research, 2017, Vol. 1, No. 4, ISSN $2548-1479$ 